\title{
PROBLEMS AFFECTING LABOR
}

\author{
BORIS SHISHIRIN*
}

I

To war workers, contract termination raises one question which overshadows all others-the question of their future jobs. Post-war employment as the source of future livelihood is the foremost concern of the vast majority of workers now performing war work. After the war, American workers want jobs above everything else. Their overwhelming preference is for real jobs in private employment. But even more overwhelming is their desire that these jobs provide a way to betterment. To them the most essential requirements of post-war employment are: (I) Income which is (a) sufficient to meet a standard of health and decent living even for the lowest paid; (b) sufficient to cover wear and tear-physical deterioration and economic attrition-inflicted upon a large part of our labor force by the sustained war production effort, overtime, and night work often performed while living under strained war conditions; and (c) sufficient to provide opportunity for economic advancement. (2) Job stability as a source of economic security.

Workers ask many subsidiary but important questions about employment to be available to them when their present war jobs are terminated. Will the new jobs mean moving to another locality or area? Will the new job be related to the work experience and training gained during the war? Will additional training, outside regular employment, be necessary in order to secure suitable employment? Will seniority rights gained in wartime be preserved in their access to and advancement in their post-war jobs? Will there be a clear cut wage policy to safeguard the basic wage standards? Will price control be retained long enough to prevent deterioration of earnings through inflation?

Current thinking among workers in war employment is characterized by extreme confidence that regular employment at fair pay will be available to them when their war jobs are terminated. This confidence extends not only to, the immediate availability of jobs after the termination of war work but also to a long term job

*A.B., I930, M.A., 193 I, Columbia University. Fellow, Brookings Institution, 1932-33. Economist, American Federation of Labor since r933. Labor Advisor, NRA, I933-r935. Member, President's Advisory Committee on Unemployment Census, I937. Secretary, Housing Committee, A. F. of L., since I937. Consultant, U. S. Housing Authority and Federal Public Housing Authority since 1937. Consultant, Office of Production Management and War Production Board, since x94I. Co-chairman, Labor Policy Committee, O.P.A., since 1942. Member, President's Committee on Fair Employment Practice since r943. Vice-chairman, National Commission on Children in Wartime since 1944. Member, Board of Directors, National Bureau of Economic Research. 
expectancy. This confidence does not seem to be supported by the prevailing postwar outlook in business, management and government or by any tangible program of action developed to date. There is still time, however, to agree upon a program of action which would help make sure that this confidence is not wholly betrayed.

Another significant characteristic of the thinking prevalent among wage earners is that while they would welcome improvement in their economic status which may be achieved through lower prices and better products they are unwilling to accept the lowering of wage standards they have attained. In general labor does not accept the "mature economy" point of view. It sees a vast post-war frontier in the improvement of income standards among the masses of low paid workers. This labor regards as the most important base on which full productive employment can be supported. The prevailing trends of opinion among workers have already been reflected in the post-war policy statements and programs of many trade unions and of their national organizations. ${ }^{1}$

\section{II}

Conversion of industry to war was compelled by one consuming purpose of the American people-to defend democracy against fascist aggression and to accomplish the military defeat of our enemies. With the defeat accomplished and with democracy victorious, what unifying principle, what single purpose will dictate the policies and procedures of contract termination and reconversion? The treachery of Pearl Harbor, the wantonness of the invading enemy in the East and in the West gave the large majority of the American people a sense of selfless dedication to the great purpose of victory. Is it possible to expect selfless dedication to a single post-war goal? Has such a unifying goal emerged in the consensus of national opinion? Will termination policies be guided by a single focal objective?

Contract termination may become a mere register of successive cessations of industrial activity no longer needed for the prosecution of the war. Or contract termination may become a most effective mechanism of purposeful transition toward predetermined and agreed post-war goals. If contract termination is to become a means of constructive action, the ends we seek must be clear.

Although contract termination and reconversion has been a consuming interest and study of many public agencies and private organizations, a clear-cut area of national agreement toward post-war policy objectives has barely begun to take shape. Since depression unemployment has been the central problem of workers in our generation, it is not surprising that labor attempted to deal with the over-all problem earlier than other groups and that it was able to express sooner the basic objectives of reconversion. ${ }^{2}$ By 1944, labor's essential post-war objectives have emerged

\footnotetext{
1 The foregoing attempt to summarize very briefly the prevailing opinion regarding post-war jobs among wage earners is based on policies formally adopted by numerous labor organizations, many reports, surveys, and polls conducted within and outside the ranks of organized labor, as well as a number of public statements by individual labor representatives.

${ }^{2}$ Cf. statement of the present writer in Hearings before the Select Committee to Investigate the Interstate Migration of Destitute Citizens pursuant to H. Res. 63, 491 and 629, 76th Cong., 3rd Sess. (1940) 3673 f. Also After the Emergency-What Then? (I94I, March) 48 AMerican Federationist 9.
} 
cleárly enough to serve as guiding principles of termination procedures. Briefly summed up, they are:

(I) Strengthening and safeguarding of democracy in the economic and industrial structure of post-war America by means of-

(a) primary reliance on private enterprise protected against encroachment by monopoly combinations and against disruption by unfair competition; (b) enforcement of civil liberties in the community and of freedom of self-organization and collective bargaining in industry and in trade; (c) provision for representative participation of workers in the shaping of administrative decisions governing or affecting production or employment.

(2) Maximum attainable employment at fair pay.

(3) Assumption by the community of positive responsibility in safeguarding the welfare of those who through lack of employment or other hazards must be assured the minimum of security through community action.

(4) Positive implementation of enduring peace.

Broadly described, the American workers' post-war objectives, unified by their interdependence are ( $\mathrm{r}$ ) freedom based on self-government, including workers' representative participation in the shaping of rules which govern employment; (2) economic security; and (3) enduring peace. Formulating these objectives in the midst of the war, labor has laid down a further paramount requirement that no termination or reconversion procedures be permitted which would directly or indirectly retard the prosecution of the war or jeopardize any portion of the productive war effort.

III

War contract termination is not a new problem. It no longer belongs to the future. In the first months of 1943 it became apparent that the rate of contract cancellations, reflecting mostly interim terminations due to the normal turnover of contracts, was markedly increased by what might be called final terminations. It was no longer the case of a contract being terminated or withdrawn with respect to a particular contractor with further related work transferred to another firm, but was now the result of fulfillment of total war requirements for a given item. This was apart from terminations of contracts for production of a great number of special items which called for only short term output, present throughout the entire program.

Orders for a number of major defense items were placed on a large scale very early in the defense program. Many military and related items had been put in production on orders from our armed forces and from abroad long before the defense program was launched. On some of these major defense items production quotas were filled early in I943. By that time we had produced all we needed for direct use as well as for the reserve stockpile of these items-our need for the duration of the war was fully met. 
In the course of 1943 the pace of cancellations was stepped up. Military decisions caused us to abandon further production of certain items whose strategic usefulness was found to have ended. Some of these terminations involved the replacement of production of one item by a change-over for production of another item. Such change-overs became more and more frequent in certain classes of munitions manufacturing and aircraft production. Discontinued production of certain types of tanks in which no provision was made for immediate utilization of plants and of a large number of workers for other work served to attract public attention in the second quarter of $19433^{3}$ The peak for contract production of a number of leading items was passed sometime in 1943. In the case of tanks for example, while the total r943 output was 13 percent higher than 1942, in the fourth quarter of 1943 tank production declined to an annual rate $\mathrm{I} 7$ percent below 1942. The 1944 program for tanks was scheduled at 25 percent below the 1942 rate of output. Curtailment of small arms manufacturing came somewhat later in 1943 but was more precipitous, indicating at least at 40 percent drop from 1943 to 1944 .

Despite these cuts the scheduled 1944 production program was estimated to be nearly $3^{\circ}$ percent greater than in 1943 . It seemed problematical, however, how fully these advanced schedules would be translated into actual production. A factor limiting the production pace was the need to produce a major proportion of war material for stockpiles to be held in reserve for full offensive operations. It was clear that the launching of the offensive and the depletion of stockpiles would call for a renewed production activity for replacements and direct use. In 1944 the over-all prospect was for a substantial increase in total war production where curtailments and terminations in the production of specific items would be more than offset by additional requirements for other items. ${ }^{4}$

At the beginning of 1944 more than ro,ooo contracts had been terminated or were in the process of termination with total value in excess of $\$ 9$ million. There were indications that, in order to avoid too drastic a dislocation of employment, production of certain items was being tapered off more gradually than the military needs for this production would justify.

It is clear, therefore, that the problem of contract termination with all its elements has already arisen and has already become an immediate issue. The presence of this problem now emphasizes the fact that during the war contract terminations involved distinct problems and called for different treatment from post-war contract terminations. While this is true of all phases of transition from war production to civilian production, it is vital to distinguish between the issues of labor policy raised in each phase.

It is especially important to realize that procedures devised to deal with duringthe-war terminations will to a large extent establish precedents and patterns which will inevitably influence post-war termination policies. During-the-war terminations,

\footnotetext{
${ }^{3}$ War ánd Post-War Demands for Trained Personnel (Institute of Women's Professional Relations, New London, Conn., r943), esp. statements by Philip Murray and Boris Shishkin, pages $23,49$.

- Figures cited above are based on the published data of the War Production Board.
} 
moreover, can be so administered as to mitigate the shock of the necessary abrupt break in war employment when hostilities cease.

Demobilization of our war labor force can no longer be regarded as a single post-war problem. Contract termination in terms of demobilization must be viewed in three stages of development: (I) during-the-war termination before victory in Europe; (2) during-the-war termination before victory in the Pacific; and (3) post-war termination after cessation of all hostilities.

During-the-war terminations in the first category have resulted and will continue to result in much waste of manpower and serious hardship to thousands of war workers. There has been and is bound to be considerable interim of unemployment before these workers find other wartime jobs. The basic problem here, however, is that of relatively short term unemployment and of mobility to other jobs more or less readily available in other war industries. A substantial cause of cutbacks has been the fact that in many sections of war production, especially in ordnance, most of the production has been for reserve stock and not for the immediate battle use. Once the European invasion is fully underway, further production for replacements will be needed for a number of ordnance items. To that extent at least some of the pre-invasion cutbacks must be regarded as temporary, and as not indicative of the employment trend. Such is not the case, however, with the production of many raw materials including extraction and refining of much of aluminum, copper, and other wartime metals.

The length of the intervening stage between the two victories will largely determine the extent of employment disruption and our preparedness to meet it when victory becomes complete. The most immediate and urgent attention must, therefore, be directed first to the specific policies and procedures governing the current terminations and to the more comprehensive methods needed to meet the first large curtailments when victory over the Nazis is complete.

I will not attempt to evaluate the size of the demobilization problem facing labor at each stage. Possible patterns of shifts in the labor force from war to peace have been developed on the basis of a number of alternative assumptions in the excellent work done by the Post-War Division of the Bureau of Labor Statistics. Suffice it to say that after victory in Europe we will undoubtedly have to meet a substantial curtailment in the size of the armed forces, that curtailment of manufacturing employment at this point is likely to displace nearly 4 million workers, and that no potential net job expansion adequate to absorb these workers can now be foreseen in either non-manufacturing industry, trade or agriculture.

The size of the demobilization problem after total victory will of course be much larger. The now visible potential for the absorption of demobilized soldiers and workers after the war is chiefly in trade and services, and in such gainful occupational groups as self-employed, proprietors, etc. During the first four years of war agriculture released nearly 5 million persons to armed forcẹs and in shifts to nonfarm employment. It does not seem probable that, at the very most, more 
than 2 million can be reabsorbed in farm employment after the war. This underscores the great need to provide productive jobs in industry and trade, if unemployment is to "be kept down to a minimum reasonably approximating that achieved in wartime.

Much of industrial demobilization will, of course, coincide with the demobilization of those in the armed forces. The major sources of reabsorption of workers and soldiers thus released may be expected in trade, finance services, and construction. Some of the durable goods industries, such as electrical appliances, refrigerators, sewing machines, textiles, lumber and paper, can be expected to expand more rapidly than others offering more immediate job opportunities. It seems inevitable that the automobile industry with industries depending on its rate of production will decline sharply before it can climb back to a level of peace-time employment of about 600,000 workers. Even after this readjustment the employment potential of automobile manufacturing is bound to be considerably lower than the volume of employment this industry maintained when converted to war production.

Declines in manufacturing will center around the key war industries. Aircraft production alone is likely to release some $\mathrm{I} \frac{1}{2}$ million workers. Shipbuilding is another war industry which is bound to undergo a drastic cut in jobs. Machinery, machine tools, iron and steel, aluminum and other non-ferrous metals, production of chemicals and petroleum products will likewise curtail employment. This will be accompanied by curtailment of government employment and some decline in transportation and public utilities.

In January I944, there were 6.5 million more employed workers on payrolls than there were in January $194^{\circ}$. Despite cutbacks, curtailments and readjustments on some sectors of our employment structure, it seems likely that total employment will increase by another 500,000 at the critical stage of invasion.

War has brought about an enormous shift from peacetime unemployment before the war to full employment in wartime. In 1940 about 9 million of our wage earners were unemployed. In this transition the normal limits of the labor force were considerably expanded. Nearly 4 million students normally in schools and colleges before the war were drawn into armed services and wartime businesses. A large number of women who would not normally be employed as wage earners entered the labor force for the first time. In manufacturing alone, between October I939 and October I940, while employment of men increased 42 percent, employment of women nearly doubled. A substantial number of persons over 65 were also drawn into the labor force.

To provide jobs for demobilized soldiers and war workers it will be necessary not only to provide expanded work opportunities, but also to achieve a measure of withdrawal from the labor force of such classes of workers as may be dictated

'Unemployment for January $194^{\circ}$ is estimated by the Bureau of the Census at 8,800,000. The A. F. of $\mathrm{L}$. unemployment estimate for the same year is almost a million higher. The difference is largely in the definition of unemployment. 
by sound public policy. If proper provision is made for educational and training opportunities for young persons, withdrawal of minors from the labor force will be facilitated. Tightened enforcement of child labor laws will also be imperative. Renewed application of peacetime standards limiting the hours of work for women and prohibiting their employment on night shifts will also offer some help in achieving at least a partial withdrawal from the labor force of women workers who entered employment during the war. Provision of sufficient old-age benefits under the social security program will likewise aid in the removal from the labor force of superannuated workers.

It is probable that a great many workers drawn into wartime employment will actively seek employment after the war and will have to be counted as a part of the labor force. The extent to which voluntary withdrawal from the labor force can be achieved will substantially modify the size of the post-war unemployment problem. While specific forecasts of the extent of unemployment that may be anticipated in the demobilization period are extremely hazardous, there is no basis for expecting today that at least temporary unemployment in the two years immediately following cessation of all hostilities will not be of critical proportions, The range of between Io and 20 million unemployed has been indicated by : number of careful students studying the problem. ${ }^{6}$

Several factors combine to support the view that post-war unemployment will be not only severe, but also difficult to overcome, unless a far-reaching program of concerted action is formulated well in advance. One of the most important among these factors is increased productivity achieved in industry during the war.

The tremendous drive for maximum war output resulted throughout war industries in unprecedented technological advances. During the past four years, productivity of labor as a direct result of intensified human effort has also shown a notable increase. Much of the technological change and the accompanying increase in work effort has remained hidden by other factors inevitable in the course of extremely rapid industrial expansion and under the impact of wartime shifts of manpower. Large recruitments of new workers, excessive turnover and delays in the supply of materials and parts have combined to conceal the trend in many of the major war industries. In fact in I940-4I over-all productivity in several war industries registered a temporary drop, accounted for partly by the influx of inexperienced help, partly by tooling up delays and partly by deficient management and supervision.

\footnotetext{
- These estimates refer to the relatively short range of readjustment, mostly confined to two years immediately following total victory. Some evaluators of the post-war employment prospects assume long range peacetime unemployment to be around 4 million. E. g., Transition to Peace (I944, Jan.) 29 Fortune 84. A more optimistic view on the immediate post-war prospects is expressed in SchiotrerBECK, Post WAR REEMployment (Brookings Institution, 1943). This study, however, also recognizes that displacement of workers will be in the aggregate of $17,800,000$. It places the possible rate of discharges as follows: in 12 months after victory in Europe-6,400,000; in six months after victory in Asia-6,900,000; in the second six months after final victory-2,500,000; in the third six months2,000,000. This study also places the long-range post-war unemployment at a high level of between 4 and 5 million.
} 
Even so, there is evidence that in most industries labor productivity attained far more than offset the slowing down effects of these adjustments. Roughly measured, but after due allowance for discrepancies of the available data on factory employment, hours and physical output, between 1939 and r 943 productivity per worker per hour increased about 20 percent. When hidden increases in productivity are accounted for, the over-all productivity of labor $^{7}$ will be likely to be found to have gone up some 30 percent in the last four years with a further increase indicated in I944.

Contract termination will be a dominant factor in determining the scope and pace of post-war unemployment. Policies governing termination will also serve to determine the scope and pace of reabsorption of displaced workers. Hence labor's keen concern in the policies and procedures of termination which constitute the - most important mechanism for achieving a controlled and balanced transition.

IV

The development of defense and war production was driven by one compelling force-speed. While special pleading from particular localities proved effective in the allocation of many new plant sites and in the approved expansion of new capacity, the growth of new production, and with it of new employment, was shaped primarily by the need to get as much essential production underway as rapidly as possible.

Conversion of industry from peace to war production was carried out without a master plan. Problems were met as they arose. Approval of a new plant site depended on a combination of particular factors in each particular case. Although in a given case availability of manpower and proximity to raw materials may have been of great importance, sufficient supply of electrical power or transportation facilities often proved decisive in determining where new production would be located. As a result, allocation of war production and war employment became badly unbalanced both in terms of distribution of productive activity during the war and in terms of reconvertibility after the war.

In the early stages of the defense program it was intended to locate the bulk of strategic capacity between the Alleghenies and the Rockies for reasons of defense against outside attack. This pattern was never realized. The propensity of procurement officers to deal with firms previously known to them and tested by them and their inclination to give preference to the larger industrial aggregates proved to be a more powerful influence than any of the over-all policies urged by the successive war production agencies-NDAC, OPM, and WPB.

The result was an overconcentration of metal-working war industries, including munitions, in a group of North Atlantic states-Massachusetts, Connecticut, Rhode Island, New Jersey, and Pennsylvania, and a group of North Central states-Ohio, Illinois, and Michigan. The aircraft and shipbuilding industries became concentrated along the seaboard of the country with heavy concentrations in the northern

${ }^{7}$ Recognizing the wide disparity in efficiency among war plants engaged in the same production. 
portion of the Atlantic seaboard, the northern and southern ends of the West Coast, and in portions of the Gulf Region. As shown by the ration book registration in April, 1943, there was a large shift of population to all border states of the country and in the three industrial states named. In general, the states in the interior registered a population loss, with the outflow directed both to the areas of war production concentration and to the armed forces.

The unevenness of the resulting concentration of war employment is illustrated by the estimate that in the industrial state of Michigan more than 6 demobilized servicemen and released war workers will apply for jobs for every to workers employed in this state before the war. In Connecticut and Indiana the ratio will be at least $4^{1 / 2}$ to Io. In the Dakotas, the Carolinas, Mississippi and Vermont the ratio will be only 2 to ro.

This unequal strain will fall even more heavily on the individual communities in which war production and employment were overconcentrated. In San Diego and in Wichita, Kansas, factory employment increased sixfold since 1937; in Seattle, Washington, and Norfolk, Virginia, it more than doubled. In Portland, Oregon, factory employment increased more than $2 \frac{1 / 2}{2}$ times. $^{8}$

In terms of putting wartime plants and equipment to best peacetime use, transition from war to peace employment presents two distinct problems. First, we have a large group of industries whose activity was curtailed by the war and which can build back their production volume and employment as materials become available. In the same general group also are the industries which are more or less readily reconvertible. Such reconvertibility implies that wartime plant machinery and equipment can be put to peacetime use in a relatively short time without a major change in the productive process, and possibly with no need for Government intervention.

In the second group are industries in which plants must undergo a basic change in machinery and equipment and which cannot go into peacetime production until after a long period of readjustment. This group also includes the plants that must be classed as "nonconvertibles." These include the majority of plants manufacturing explosives, shell-loading, and bag-loading plants. In the same class are plants whose equipment is theoretically convertible but whose equipment can be of no use because it represents excess capacity. By far the largest portion of our aircraft production plants are in this category. The major portion of shipyard capacity presents the same problem.

This second group of industries represents a definite distress area which requires special treatment. A great many of these plants are the result of a huge investment of public funds not only in the productive equipment they contain, but also in the supply of power, utilities, and transportation facilities, as well as community facilities and housing that had to be provided to service them. We can

\footnotetext{
- Pierson, Employment After the War (Post-war Planning Committee of the American Federation of Labor, 1943). See also Emile Benoit-Smullyan, Relative Severity of Post-War Demobilization (I943, July) 57 MONTHLY LABOR REv. I.
} 
salvage much of this machinery and equipment and put much of the supporting power, transportation facilities, etc., to full productive post-war use if an agreed plan is developed for special treatment of this distress area of reconversion. The size and nature of the problem is such that government participation in planning and assisting the transition is clearly necessary. The enormous shipyards on the Columbia River around Portland will no longer be needed after the war. All supporting facilities in that area will become scrap if not put to productive use. Yet the location of these yards offers such great natural advantages for production and shipping that the conversion of the shipways to entirely different production uses could offer the most economical way to new industrial development capable of supporting a large and steady employment growth.

Termination policies in the first group of industries may generally assume that private enterprise càn solve the basic problems of reentry into civilian production without outside aid. Termination procedures should serve merely to facilitate that transition and safeguard the public interest inherent in it. Termination of contracts in the second, the distress, group, on the other hand, will determine the future utilization for expanded employment of a huge war-time public investment. Here the entire solution of the problem must depend on public policy and not on whatever private interests may be involved.

This distinction illustrates the need for integrated treatment of contract terminations procedure in a way which makes it possible to relate guiding policy decisions to other major policies of the government directed toward stabilization of employment after the war. Such integration can be achieved only through a unified policy approach governing the entire termination program.

\section{$\mathrm{V}$}

American industry was converted to war production with virtually no advance planning and very little preparation. Conversion between 1939 and 1943 was notable for the lack of consistent guidance from the Government to industry and labor on basic conversion policies and lack of coordination among the various Government agencies concerned. Despite ceaseless conflicts of responsibility and overlapping of jurisdiction of different agencies along the entire war production front the record of American manufacturers and workers in shifting into war production was truly outstanding. But the speed of peace-to-war conversion reflects more the strength of purpose on the part of our entire industry to take part in the war effort than the effectiveness of the basic war production administration.

By the time the largest part of conversion from peace to war was completed, a very substantial progress had been made in putting the Government's war production administration in order. The introduction of the "controlled materials plan," although belated and cumbersome, equipped the War Production Board with the essential coordinating controls which it had lacked. A measure of coordination was achieved in the relationship among claimant agencies in procurement proce- 
dures. But even the establishment of the Office of War Mobilization did not result in the positive coordination of the several procurement and administrative efforts, nor did it produce such over-all planning of the industrial war effort as labor and other groups had sought. Throughout the program, multiplicity of conflicting war agencies was matched only by the multiplicity of conflicting Congressional committees investigating them.

Thus, in I943, industrial America faced the problem of transition from conversion to reconversion, lacking a central agency for planning and coordinating an orderly change. Reconversion, therefore, was not a matter of throwing central controls in reverse. It was a matter of first devising such controls for an orderly transition to peacetime enterprise and employment.

During 1943, back-flows and eddies began to develop in the gigantic flow of war output. Military requirements for war production reached a stage where termination of contracts in some sectors of war procurement became an immediate necessity while the need for expansion of activity in other major sectors continued to be pressing. These conflicting trends only enhanced the three elements essential to balanced reconversion procedure: ( $\mathrm{I}$ ) advance planning; (2) genuine coordination of Government policies and responsibilities; (3) timing of contract cancellation and demobilization.

To achieve these, labor proposed the creation of a single demobilization agency with central power to determine basic policies whose execution would rest with several operating agencies. Because reconversion policies will reach far in shaping the future of manufacturers and workers, and because they must of necessity involve quick and sweeping decisions, labor urged that adequate representation be given to management and labor at the top policy level of the central demobiliza. tion agency.

In dealing with reconversion and contract termination, labor's first objective is to set up the most effective mechanism which would enable representatives of labor and management to join with the government in formulating the basic policies of demobilization, reconversion, and reconstruction which will soon confront the nation.

Administrative unification, which was never fully achieved in the development of war mobilization, is imperative in demobilization if agreed post-war goals are to be met through a concerted program of action. Such unification is made essential by the far-reaching interdependence of basic factors controlling policy decisionsavailability of raw materials, the most effective utilization of demobilized plants, machinery and equipment, disposed of war stocks and surplus materials and, above all, the most effective reallocation of demobilized workers to civilian productive jobs. Administrative policy unification is equally necessary to achieve sound and balanced procedures in the face of powerful conflicting pressures inside and outside the Government. What looks to the Comptroller General like a saving of a few million dollars in a particular termination transaction, may mean a loss of many 
millions of dollars to the community in terms of lost jobs and deteriorating plant capacity this initial saving may entail. The sale of a particular stockpile at a rigged price by a procurement agency may look like a saving on the books of a procurement agency, but may mean a complete disruption of the market for that and related commodities, wiping out a strategic source of post-war job opportunities.

Labor asks for a voice in the shaping of policies which will guide the course of demobilization and of contract termination. It does not seek to intervene in management. But labor is unwilling to delegate policy decisions which will shape the future course of employment to the omniscience of another "czar" uncontrolled by the practical experience and representative expression of labor as well as management. Singleness of purpose and harmony of action can best be achieved in such participation of labor and management in the formulation of reconversion policies.

What labor has long sought in administration of war mobilization and what labor has urged in war demobilization-single unified civilian controls over policy and administrative-has never been achieved in practice. The Baruch-Hancock report ${ }^{9}$ has accepted the major premise laid down by labor spokesmen for central administrative controls. However, neither the Baruch report nor the George-Murray Bill which embodied the main recommendations of the report has accepted labor's major premise that procedures governing reconversion of plants and properties and procedures governing demobilization of manpower must be administered under a legislative program governing, a single set of controls.

Early in May, r944, it became clear that reconversion procedures confined solely to the handling of war plants and properties would be submitted to Congress for consideration before the summer recess scheduled for mid-June. The GeorgeMurray Bill, the leading measure prepared for final Congressional consideration, left out of account programs necessary to provide for human needs and assure employment opportunities for demobilized workers and soldiers. In a joint statement of the American Federation of Labor, the Congress of Industrial Organizations and the Railway Labor Executives Association, labor condemned the onesidedness of the George-Murray Bill, with vigor and unanimity. At the same time labor gave its full support to the Kilgore Bill.10

The Kilgore Bill proposes to set up machinery in the Office of War Mobilization to meet the major problems of both labor and industry in the reconversion process. It provides for the establishment of a National Production-Employment Board with representation of industry, labor, agriculture and consumers. Given full access to all the data in the Office of War Mobilization bearing on the effectiveness and adequacy of the program, the proposed Board would not only advise the Office of

\footnotetext{
${ }^{\circ}$ Bernard M. Baruch and John M. Hancock, Report on War and Post-War Adjustment Policy,
} SEN. DoC. No. I54, 78th Cong., 2d Sess., I944.

${ }^{10}$ S. 1893, 78th Cong., 2d Sess. (1944). 
War Mobilization on policies, but also endeavor "to secure maximum cooperation and participation of the American people in war mobilization and post-war adjustment."

The Kilgore Bill contains detailed provision for retraining and reemployment of demobilized workers and spell out the responsibilities of the Government for defraying the cost of transportation of workers and ex-servicemen from their previous residences to new jobs. Maintenance allowances for those enrolled in vocational training programs are also provided. The Bill contains a provision for "interim placement benefits" to tide demobilized workers and soldiers over the period of temporary unemployment in the course of reconversion.

To be sure the Kilgore Bill is by no means the last word in an over-all plan for concerted reconversion and demobilization. It is, however, far the most comprehensive plan for integrated machinery through which labor, industry and the Government could work together effectively to prevent economic collapse and protect wage earners against needless suffering. Labor will continue to press for the Congressional enactment of the basic provisions of the Kilgore Bill governing human demobilization and will seek intergrated administration of these provisions with those governing reconversion of plant and property. ${ }^{11}$

\section{VII}

Labor is fully as concerned with the administrative procedure governing terminations as it is with matters of legislative policy. Termination of war contracts can be most effectively planned and executed if made part of an integrated procedure subject to centrally made over-all policies. This does not mean that uniformity of procedure in all cases is either possible or desirable.

War contracts differ widely in the terms on which they were let, the conditions of performance and the method of determining the cost to the Government. These differences occur within a single procurement agency. Other basic differences distinguish procedures among different procurement agencies. From the network of prime contractors who deal directly with the Government spreads a more complicated web of orders let to subcontractors and to sub-subcontractors. A single contractor, dealing with several procurement agencies and handling several types of contracts must often follow different accounting procedures with respect to each class of work and each agency. The Procurement Policy Division of the War Production Board succeeded in introducing a measure of coordination among agencies. The coordinating policy board evolved among procurement agencies acts to some extent as a clearing house through which work discontinued by one agency may be transferred to another.

Not only has the unification of procurement procedures fallen far short of wartime need, but no agency has been developed to assume responsibility for meeting peace-time requirements of civilian economy. Planning for post-war production

12 For statement of labor views cf. Reconstruction Administration (report of the A. F. of $L$. Committee on Postwar Planning, January, 1944); Postwar Program (A. F. of L., April, I944), p. 23. 
and employment is vastly different from the task of scheduling military procurement. The post-war task cannot be performed without a completely reorganized procedural set-up, with clear responsibility toward reaching clearly established goals.

Termination clauses in war contracts should be so formulated as to best meet special problems of production and employment encountered in each type of procurement. A termination clause, moreover, inevitably conditions the cost, price, and production policies of the contractor in the course of war production, as well as determines the contractor's post-war pattern of action.

Although designed to achieve fullest possible employment after termination, cancellation clauses and procedures must not encourage labor hoarding, wasteful use of labor or extravagant spending for overhead. Hoarding of under-utilized labor and uneconomical plant use will lead to inflated costs and distorted prices which only serve to jeopardize long-run employment stability. An unduly liberal termination settlement, making a generous profit allowance on work in process and on inventories would serve to encourage overbuying of materials and accumulation of wasteful surpluses.

Termination and liquidation policies must be guided, above all, by the central post-war objectives of the entire reconversion program. Full account should be taken of the special interests of the contractors attempting to gain advantageous competitive positions in the post-war market. In the case of all terminations made while the war is still on, strong safeguards are necessary to prevent a stampede of essential war producers for the civilian post-war market at the expense of essential was production. At the same time, positive incentives are necessary to assure prompt conversion of production facilities of those contractors whose capacity is no longer needed for war requirements.

One of the most difficult policy problems in this connection is created by the tendency on the part of the procurement agencies to rely heavily until the very end on the most efficient producers for the supply of war requirements. Unless a definite attempt is made to distribute terminations over the entire range of the particular industry, much of the gain in labor productivity, efficient management and advanced technology may be lost for post-war production.

Distribution of terminations must be closely related to the kind of distortions forced in the pattern of a particular industry by war needs. Concentration programs of the War Production Board have put the burden of war production on large industrial units in some industries and on small producers in others. In reconversion, different types of producers must be treated equitably, the pattern of competition must be safeguarded and maximum job opportunity assured. Scheduling of cancellations must be closely related to these essentials for post-war growth. They cannot be dictated solely by the decisions of military procurement agencies. Nor can they be made workable and sound without full participation of labor and 
management in the formulation of plans, rules and schedules in each branch of industry.

In arriving at a termination pattern, it must be remembered that war mobilization has set off an enormous drive toward industrial concentration. Over threefourths of all defense and war contracts have been handled by only roo firms. This over-concentration is a real threat not only to the post-war competitive growth, but also to the balanced expansion of post-war employment. Before the outbreak of the war, smaller manufacturing plants were the source of nearly one-third of the nation's industrial employment. These smaller plants are important in providing wider distribution of post-war jobs and are in general capable of achieving reconversion more rapidly.

Dominant consideration must be given to the scheduling of cancellations in direct relation to the distribution of industrial manpower. For almost a year duringthe-war cancellations have been completely unrelated to the geographical pattern of manpower distribution. No single approach to this problem is possible. For example, in the case of bag-loading plants, many of which are located in isolated rural areas, and where, say, a 50 percent reduction may be necessary, it would be wiser to shut down half the plants and transfer all workers elsewhere rather than cut in half employment in all these plants. In other words, if it is recognized that the plant is not immediately convertible and the area is bound to become a ghost town, it would be better to transfer the displaced workers to industrial areas where there is still demand for labor and where prospects for conversion are better. On the other hand, where plants are readily convertible, termination may help to loosen up extremely tight labor areas and bring new production to relatively loose areas.

The job of giving due weight to the several necessary considerations which must underlie termination scheduling, is extremely complex, but not impossible. Several devices in which management and labor can cooperate may prove extremely effective if developed in advance. One of these is the development of an industrywide inventory by each industrial group, of productive machinery and equipment to establish concrete and integrated basis of information regarding potential convertability. A uniform system of reporting by members of industry would enable the Government to develop a coordinated depository of information on which that industry or other industries could heavily rely. A similar inventory of raw materials in the hands of war contractors, the amount of work in process, the contractor's stock of finished goods and the surplus stock accumulated by the armed forces would greatly facilitate the development of an over-all plan.

Parallel to these inventories of productive equipment and materials would be the development of an inventory of skills. The availability of such an inventory of occupational distribution of manpower would aid the flow of displaced workers to jobs for which they are best qualified. In many areas of employment the exact- 
ing task of occupational classification could be greatly furthered by active participation on the part of organized labor.

Within the broad administrative framework of unified and cooperative development of policies and procedures falls the challenging task of developing techniques which would make sure that cancellations conform to requirements of a sound cost and price policy. Uniform accounting procedures would greatly speed contract settlements and facilitate adjustment of contract claims on a plant-wide or producerwide basis. Company-wide terminations thus made possible in many cases would greatly accelerate the pace of war to peace conversion.

Labor's concern, however, is not only with the speed of contract settlement which enables the employer to shift more rapidly to peacetime activity, but also with the cost and price policies which underlie such settlement. Loosely conducted and poorly safeguarded cost and price contracting procedures are hidden elements of a future inflation in a period in which downward pressure on wages will be great.

The problem may be illustrated by a brief mention of special reserves for reconversion. Provision of reserves which can facilitate the change-over to civilian production and help to achieve lower prices has value in individual situations provided they are developed in a setting in which the health of the entire economy is assured. The usefulness of special reserves is extremely limited unless financial liquidity can be attained through other adjustments. In themselves corporate post-war reserves offer no sure way toward stable post-war growth. Reserve accounts on the books of a corporation are not funds which can pay for machinery, repairs and distribution of products. Special reserve accounts treated as allowable costs for tax purposes, lend themselves easily to dangerous abuse. Far safer is direct and controlled determination of reconversion costs with direct aid for their financing. ${ }^{12}$ The use of bank loans insured by the Government under a plan similar to that used by the FHA for housing may be one solution that will help us avoid direct Government lending and at the same time escape hidden profiteering and concealed inflation possible if special reconversion reserves are classed as allowable costs.

As there is no patent on victory in war, there is no patent for winning the peace. Neither labor, management nor Government can accomplish the major task of termination and reconversion singlehanded. The cooperation of all three is essential to get the job done, and to get it done in a way in which no single group will gain a special advantage in the establishment of an orderly transition to a dynamic and healthy post-war economy.

\section{VIII}

Contract termination raises a number of issues of trade union policy. This is especially true in industries and occupations whose ranks have been greatly swollen

${ }^{12}$ For general analysis of the problem, see MArk Massel, Business Reserves for Post-War Survival (National Planning Association, Wash., D. C., 1943). 
by war demands, such as shipbuilding, aircraft, explosives, aluminum, copper and. other metal working industries, and in mechanical and metal working trades. How can unions aid in the transfer of members to civilian work when war jobs are terminated? What role will labor assume in the difficult process of integrating the returning servicemen into post-war jobs? What effect will the war-time breakdown of skills have on the peace-time standards established by collective bargaining?

A serious question to millions of workers transferred to essential war jobs and frozen in these jobs during their war employment is-what credit will be given them in their peacetime classifications for this wartime experience and training? Tangible seniority rights have been established by wage earners in industry only through collective bargaining. Outside the framework of a voluntary collective agreement, seniority does not exist as a right. Nor can the right of seniority be established by law.

Outside the incomplete file of registrations of the U. S. Employment Service, no record of wartime employment has been maintained. As a system of wartime job registration was not conceived in the early stages of defense and war programs, it would seem hardly feasible to construct the war employment record of millions of workers frequently shifted between jobs and industries. Only in occupations in which the record of job assignments is kept by a government agency as a matter of course, as in the case of wartime shipping, would it be at all feasible to provide war workers with a certificate of war service, for credit to post-war seniority.

The responsibility for the estalishment of wartime seniority after the war is clearly a task which only unions can fulfill for their members. The inevitable occupational shifts which are bound to change occupational status and union affiliations of a great mass of workers present a challenge to the labor movement which may be fully met only through a cooperative plan which would assure every union member of a square deal and a full recognition of his wartime experience.

Proposals to provide workers with dismissal or separation pay when their war jobs are terminated have commanded much attention. It has been suggested that such dismissal pay, designed to give war workers at least some means to tide them over between their war job and peace employment, would be chargeable to the Government by the war contractor on the ground that such "muster out" pay to the war worker is a part of the cost of the war.

The initial proposals of the dismissal pay plans came from the employers' side and not from labor. It was clear that the early impetus given to the dismissal pay plans was not so much the concern with the welfare of the dismissed worker as the desire on the part of the war contractor to have such dismissal pay classed as allowable cost for tax purposes. 
The likelihood of a practical application of a general dismissal pay plan seems remote despite the lack of strong opposition to it. The chief obstacle is the diffculty of clearly defining the coverage of such a scheme. If the plan is limited to prime contractors only, dissatisfaction on the part of workers who have been repeatedly classified as war workers, but who will be denied dismissal compensation is bound to be widespread. If, on the other hand, the plan is extended to cover war subcontractors, the administrative difficulty of defining the war worker in numerous plants in which only part of employment was connected with war contracts will be well-nigh impossible to overcome.

If the coverage is extended liberally in the face of these difficulties and some 20 million wage-earners generally classed as war workers become beneficiaries, a program averaging only \$100 per worker would call for disbursement of $\$ 2,000$,000,000 in public funds. Yet a $\$ 100$ dismissal bonus which in durable goods industries will be the equivalent of about two weeks' pay, will hardly be regarded by workers as a sufficient amount to be of any help in their difficult transition from wartime to peacetime jobs. At the same time an economy-minded Congress is not likely to authorize a much larger sum, especialy in view of the limits now indicated in the muster-out pay for the soldiers.

As a matter of sound public policy, it is questionable whether the employer is a suitable disbursing agent for equitable allocation of the large public fund involved in the dismissal pay proposal. Some base would have to be established in terms of the worker's length of service in his war job. Otherwise, pre-closing payrolls may be deliberately inflated by employers anxious to become dispensers of public benefits and eager to increase their allowable costs. Once duration of war employment becomes the test of eligibility, difficulty in establishing prior war employment with other war contractors will make the administration of the scheme cumbersome, slow, and costly.

The political force behind the drive for dismissal pay is found in the quarters strongly opposed to the extension of the social security program providing for enlarged unemployment benefits such as the Wagner-Murray-Dingel Bill contemplates. Approval by Congress of both the dismissal pay plan and the enlarged unemployment compensation program does not seem probable.

The record of $x 943$ trade union agreements gives a strong indication that organized labor is acutely alert to its responsibilities toward the fellow workers who have gone into active military service to bear arms for their country. It will be remembered that the Thomas amendment to the Selective Service Act, providing the main statutory basis for reemployment of servicemen, was adopted at the initiative and with the aggressive support of organized labor. Although the provisions of this law and of the National Guard and Reserve Corps Joint Resolution of I940 provide no firm guarantee of reemployment and of resumption of adequate earnings on the job, this lack can be made up by labor's willingness to assume leadership in assuring employment preference to veterans. 
Although there is a wide variation in the reemployment provisions covering servicemen, the pattern of military service clauses in contracts has been generally well crystallized. The basic provisions developed through collective bargaining usually provide for (I) application for job reinstatement within a period ranging from 60 days to 6 months after discharge; (2) accumulation of seniority while in training or on active duty; (3) where disruption caused by reconversion makes strict application of seniority impossible, procedure for transfer to equivalent work or related employment with retention of pay status; (4) accrual of eligibility for benefits during the term of service; (5) some provision for dependents of employees who are killed or disabled in the service; (6) provision for employment of those physically handicapped in the armed service.

A number of agreements provide that employees called into service be retained on the payroll for a brief period after they leave to enter military service. There is considerable variation in the applicability of military service clauses in relation to the length of service with the employer prior to induction. Extension of such clauses to seasonal and temporary employees also varies. In general, the effectiveness of military service clauses depends on the willingness of the employer to agree to the liberal terms proposed by the union and the collective bargaining strength of the union. In I94I and 1942 the tendency of employers was to depart as little as possible from the loose terminology of the reinstatement provisions of the Selective Service Act. Agreements negotiated in 1943 show the ability of the unions to strengthen the provisions and the employers' willingness to accept more detailed and specific clauses.

Some agreements negotiated in 1943 and a greater number of those on which negotiations were still pending at the close of the year indicate new insistence on the part of the unions on some form of dismissal compensation-without regard of course to the question of whether or not such compensation would become a part of the contract cost to the government. In the early stages of our participation in the war, employers strongly resisted provisions for separation pay. In the latter part of 1943 there was greater willingness on the part of employers to meet separation pay proposals, but often on the condition that dismissal compensation be paid only if allowed as a contract cost by the Government. ${ }^{13}$

In viewing as a whole the problem of reinstatement of servicemen, it is clear that collective bargaining will play a leading role in the setting of standards and procedures surrounding reinstatement. Organized labor has taken the leadership in dealing with this issue and will undoubtedly retain it. It is also clear that collective bargaining cannot solve the whole problem. The issues involved must be recognized in the handling of contract terminations and at least a guiding

${ }^{13}$ The above brief summary of union contract clauses dealing with military service is based on a study of agreements of American Federation of Labor unions. For other material, see Cannon, MilitaryService and War-Job Clauses in Union Agreements (1942, Dec.) 55 Montrhy Labor Revew. Also Brecht, Collective Bargaining and Re-employment of Veterans (1943, May) 227 ANNALS OF THE American Academy of Political and Soctai Science 94. 
statement of policy from the Government, applicable to all types of terminations, will be essential.

To achieve a smooth and harmonious flow of reinstatement for demobilized soldiers and discharged war workers it will be necessary to put into effect a number of policies which go far beyond the limits of contract termination provisions. For example, eligibility for the payment of unemployment insurance benefits and other social security benefits must be extended by statute to soldiers and to workers shifted around the country under the pressure of war manpower needs during the war.

It is not entirely futile to hope that statutory enactments, administrative policies and termination procedures can be harmonized. A broad basis of agreements among representatives of management, labor and the Government regarding post-war objectives would enable the nation to develop an agreed advance plan ready to be translated into a program of unified, positive action. Only such a program of action, speedily carried out, can give us assurance that economic freedom and security will be achieved by the American people after the war and that democracy will withstand the strain and stress of transition to peace. 